\title{
Use of Fertilizer and Pesticide for Crop Production in Agrarian Area of Tangail District, Bangladesh
}

\author{
Trina Chakrabarty ${ }^{1}$, Shamima Akter ${ }^{1}$, A.S.M Saifullah ${ }^{1, *}$, Md. Shemul Sheikh ${ }^{1}$, Arjun C. Bhowmick ${ }^{2}$ \\ ${ }^{1}$ Department of Environmental Science and Resource Management, Mawlana Bhashani Science and Technology University, \\ Tangail-1902, Bangladesh \\ ${ }^{2}$ Department of Chemistry, Mawlana Bhashani Science and Technology University, Tangail-1902, Bangladesh \\ *Corresponding Author: saif_esrm@mbstu.ac.bd
}

Copyright (C) 2014 Horizon Research Publishing. All rights reserved.

\begin{abstract}
This study was carried out to investigate the mode of fertilizer and pesticide use and their impact on soil fertility and surrounding environment. It is revealed that paddy is the mostly produced crop in this area and fertilizers and pesticides were intensively used for boosting up the production of crops. Among all the fertilizers Urea is the mostly used fertilizer followed by Urea, MP, DAP/TSP and also organic fertilizer (although in less amount). Among the pesticides used in study area to kill pest, Furadan and Diazinon were most demanded. Farmers of this area used either greater amount or less amount of fertilizer than the standard amount provided by government. Most of the farmers and agrochemical dealers were not aware about the impact of fertilizer and pesticide on crop production and environment as well. This outcome draws base line situation which can be useful towards further relevant research as well as to develop policy in agrochemicals use in agriculture.
\end{abstract}

Keywords Fertilizer, Pesticide, Production, Dealers, Farmer

\section{Introduction}

Bangladesh is agrarian country with huge population load [28]. As the largest private enterprise, agriculture contributes about $21 \%$ to the country's GDP [24]. Fertilizer is considered one of the main inputs for increasing crop yields and farm profit. To understand the role of fertilizer for increasing production [31], cited the Nobel prize-winning wheat scientist Dr Norman E Borlaug's dialogue as "If the high yielding wheat and rice varieties were the catalyst that ignited the Green Revolution, then chemical fertilizer was the fuel that poured its forward thrust"[31]. This is also true for Bangladesh agriculture because the country has virtually no possibility of increasing its cultivable land area. So, the food production of this country can be increased through increasing irrigation facilities together with HYV and greater use of fertilizer [28]. Pesticide is another most important input for increasing crop production and protects everything from flower gardens to agricultural crops from specific pests [1]. The use of pesticides, including insecticides, fungicides, herbicides, rodenticides, etc., to protect crops from pests, allowed to significantly reduce the losses and to improve the yield of crops such as corn, maize, vegetables, potatoes, cotton, as well as to protect cattle from diseases and ticks and to protect humans from malaria vectors [10]. Using modern varieties of fertilizers and pesticides result in the increase of agricultural production. However, there have been concerns of environmental problems resulting from inorganic soil management practices [2]. Fertilizers burn, delayed emergence, injury to plant tissues, and even death of plants may also occur with fertilizer application [11]. Sometimes chlorosis may result, which is an indication of high soil $\mathrm{pH}$ due to accumulation of inorganic nutrients. References [33] reported an increase in soil microbial biomass with fertilizer application; however, their results did not emphasise the ratio of beneficial to non-beneficial organisms. On the other hand, [7] showed that the use of chemical fertilizers resulted in accumulation of carcinogenic nitrosamines in soil environments, which consequently reduced the occurrence of beneficial microorganisms. Alternative methods of soil fertility management are being developed to minimize problems associated with inorganic fertilizer usage. Therefore, it is important to study the inter-relationships between the crop and other soil factors that contribute to the productivity of a system. These include interactions between cropping systems and the microbial communities that facilitate or enhance nutrient uptake in soils. The mycorrhizal community is an important microbial component of the ecosystem. References [8] described mycorrhizae as symbiotic associations between fungi and roots of plants to form a single functional organ that is principally responsible for nutrient transfer. Beneficial associations with arbuscular mycorrhizal fungi (AMF) have been reported in many crops [30]. AMF are important in enhancing nutrient uptake [9], especially phosphorus (P) [17] in host plants. Other benefits of AMF include increased dry matter and crop yield [13] and resistance to drought [26, 32] 
and soil-borne pathogens [16]. References [18] attributed the development of efficient biological nitrogen systems to $\mathrm{P}$ uptake enhanced by AMF. However, the efficiency of AMF symbiosis may be a function of the susceptibility of the host, the community structure $[25$ and other factors relating to soil fertility. Soil fertility management practices may influence the community structure and activities of $\operatorname{AMF}[15,19,23$, and 27]. So a research Influence of fertilizer application on the occurrence and colonisation of arbuscular mycorrhizal fungi (AMF) under maize/Centrosema and sole maize systems was conducted to provide information on the effects nitrogen- phosphorus- potassium (NPK) fertiliser at different rates on the abundance of AMF spores, colonisation by AMF, nutrient uptake, and maize yield in maize/Centrosema and maize/maize systems [12]. Alternately pesticide use raises a number of environmental concerns, and human and animal health hazards. Over $98 \%$ of sprayed insecticides and $95 \%$ of herbicides reach a destination other than their target species, including non-target species, air, water and soil [21]. Pesticides are one of the causes of water pollution, and some pesticides are persistent organic pollutants and contribute to soil contamination. Unfortunately these chemicals are non-biodegradable, persistent and get accumulated in the environment and thus into the human food chain. Despite regulatory measures, these compounds continue to be detected in measurable amounts in the ecosystem including marine life [29]. This study was conducted to provide a detailed analysis of using pattern of fertilizers and pesticides in an agrarian area naming Shakrail and to examine how these have affected crop diversity, productivity, food availability and the environment, so this study can be helpful for agricultural growth to improve resource economy, productivity and efficiency in farming in Bangladesh. This research helps to know either the farmers are benefitted or affected by using chemical fertilizer and pesticide. We also able to investigate the knowledge among the farmers' about the effects of such agrochemical use on the environment, in particular, soil fertility.

\section{Materials and Methods}

\subsection{Study Area}

Sakrail is a village under the word number 5 and mouza 196 [5] near Tangail Pouroshova of Tangail district and the total area of this village is 437.78 acre. The land use pattern is dominated by residential establishments and agricultural activities. Danya bound it at north and west, Santosh at south, Dighulia at east and Enayetpur at north east (Figure 1). Shakrail has population of 2944. Male constitutes 1502 and female constitutes 1442 with 642 households. It has an average literacy rate of $39.75 \%$, where male constitutes $46.18 \%$ and female constitutes $33.12 \%$ [5].

\subsection{Data Collection}

For the purpose of this study both primary and secondary data were collected and analyzed accordingly. In this research, methods as well as interview with local people, and questionnaire survey both open ended and close ended were applied for primary data collection. Questionnaire survey was conducted on three groups of respondents. They were: a) Farmers (80), who were most directly related to the study; b) Agrochemical dealer (5) and c) Agricultural officer as key informants. Before questionnaire survey a draft of questionnaire was prepared and was tested in the field. Secondary data were collected from different sources such as research paper, journal, internet and book. Map of study area was collected as secondary data from Tangail pourashava. Then both the primary and secondary collected data were analyzed by MS Excel and SPSS 14 version program software. The findings of the study were prepared to present as percentages, charts, tabular form along with relevant discussion.

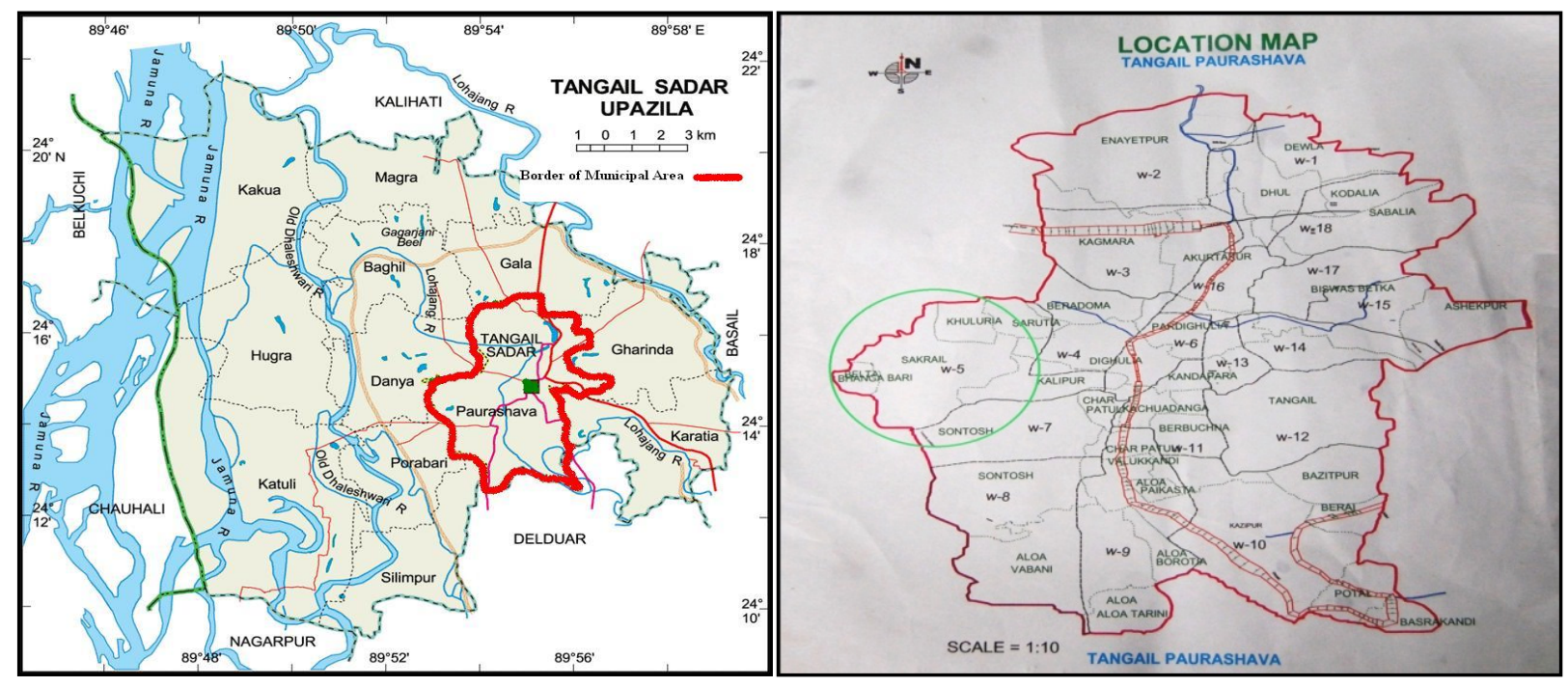

Figure 1. Study Area of Shakrail in Tangail District [6] 


\section{Result and Discussion}

\subsection{Profile of the Respondents (Farmer)}

Among the respondents (farmers) the major portion were between the age group between the age group of 41 years to 50 years $(50 \%)$ and Second largest $(27.5 \%)$ age group was between 31 years to 40 years. Most of the farmers $(43.8 \%)$ did not have any formal education, while $21.3 \%$ were of less $5^{\text {th }}$ class, $12.5 \%$ of S.S.C. level, $11.5 \%$ of primary level, $7.5 \%$ of $6^{\text {th }}-9^{\text {th }}$ level and only $3.8 \%$ of H.S.C. level (Table 1 ).

Table 1. Profile of the Respondents (Farmer).

\begin{tabular}{|c|c|c|c|}
\hline \multicolumn{1}{|c|}{ Variable } & Frequency & Percent \\
\hline \multirow{4}{*}{$\begin{array}{c}\text { Age group } \\
\text { (year) }\end{array}$} & $20-30$ & 6 & 7.5 \\
\cline { 2 - 4 } & $31-40$ & 22 & 27.5 \\
\cline { 2 - 4 } & $41-50$ & 40 & 50.0 \\
\cline { 2 - 4 } & $51-60$ & 12 & 15.0 \\
\hline \multirow{4}{*}{$\begin{array}{c}\text { Education } \\
\text { level }\end{array}$} & Total & 80 & 100.0 \\
\cline { 2 - 4 } & Illiterate & 35 & 43.8 \\
\cline { 2 - 4 } & Less 5 & 17 & 21.3 \\
\cline { 2 - 4 } & Primary & 9 & 11.3 \\
\cline { 2 - 4 } & 6th-9 & 6 & 7.5 \\
\cline { 2 - 4 } & S.S.C. & 10 & 12.5 \\
\cline { 2 - 4 } & H.S.C. & 3 & 3.8 \\
\cline { 2 - 4 } & Total & 80 & 100.0 \\
\hline
\end{tabular}

\subsection{Profile of the Respondents (Agrochemical Dealer)}

It is revealed from the respondents ( pesticide and fertilizer vendor) that $60 \%$ of the agrochemical dealers were found between the age of 41 years to 50 years and $40 \%$ were between the ages of 30 years to 40 years. About $40 \%$ of the respondents completed S.S.C. level and 40\% completed H.S.C. level. Only $20 \%$ of the respondents completed graduation.

\subsection{Profile of the Key Informants (Agricultural Officer)}

Agricultural officer were also interviewed (Field survey 2012) as key informants. Among these respondents, only one person was Agricultural Extension Officer and remaining four were Plant Protection Officer. Among the respondents, $80 \%$ of them completed diploma engineering in agriculture and $20 \%$ completed graduation. It was also found that $60 \%$ were in age group of 40 years to 45 years, $40 \%$ belong to the age group of 46 years to 50 years.

\subsection{Use of Fertilizer and Pesticide in the Study Area According to the Farmers}

The study tried to investigate the farmer's perception about the use of fertilizer and pesticide in crop production and their impact. Farmers' perceptions have been presented here. From the study it was found that the main crops in our study area are paddy, jute, mustard and vegetables. About
$58.8 \%$ of the respondent produced only paddy, where $13.8 \%$ produced jute and $10 \%$ produced mustard respectively in combination with paddy and $11.3 \%$ produced all of the three crops: paddy, jute, mustard, and only $6.3 \%$ produced multi-crops including all of the crops mentioned above. It was revealed from the study that in that area farmers usually used different fertilizer for different crops such as, for paddy production the largest group $(33.8 \%)$ of farmers applied Urea, T.S.P. and M.P. The second largest group (26.3\%) applied Urea, M.P. and D.A.P. / T.S.P. Here this group of respondents uses D.A.P. in some cases and use T.S.P. in other cases. In case of Jute and Mustard farmers used Urea, T.S.P., M.P., and D.A.P. etc (Table 2).

Table 2. Use of Fertilizer for Paddy, Jute and Mustard cultivation.

\begin{tabular}{|c|c|c|}
\hline $\begin{array}{c}\text { Crop } \\
\text { Category }\end{array}$ & Name of fertilizer & $\begin{array}{l}\text { User } \\
(\%)\end{array}$ \\
\hline \multirow{6}{*}{ Paddy } & Urea & 2.5 \\
\hline & Urea,D.A.P. and M.P & 21.3 \\
\hline & Urea,T.S.P. and M.P. & 33.8 \\
\hline & Urea ,M.P. and D.A.P./ T.S.P. & 26.3 \\
\hline & Urea, M.P.,D.A.P. and Organic fertilizer & 12.5 \\
\hline & Urea, M.P. ,T.S.P, Zinc-sulphate & 3.8 \\
\hline \multirow{3}{*}{ Jute } & Urea, T.S.P. and M.P. & 31.3 \\
\hline & Urea, D.A.P .and M.P. & 12.5 \\
\hline & No comment & 56.3 \\
\hline \multirow{3}{*}{ Mustard } & Urea, M.P. and T.S.P. & 8.8 \\
\hline & Urea and M.P. & 12.5 \\
\hline & No comments & 78.8 \\
\hline
\end{tabular}

The study result showed that the farmers of the study area did not follow in using the Bangladesh Government recommended standard amount for particular fertilizer. From the survey it was also found that in case of T. Aus of using Urea the largest group (45\%) of farmer applied 201 to 250 $\mathrm{Kg}$ per hectare of crop land, where the second largest group $(23.8 \%)$ of farmers applied $251 \mathrm{~kg}$ to $300 \mathrm{Kg}$ Urea per hectare of crop land, $18.8 \%$ of them used $151 \mathrm{Kg}$ to $200 \mathrm{Kg}$ Urea per hectare where farmers used greater amount of urea then the standard amount (Table 3 ). In case of T. Aman, Larger group of farmers $(76.3 \%)$ used greater amount of Urea and many of them used very high amount in compared with standard amount of Urea provided by MOA [22]. In comparison between the standard amount and actual amount of MP used by farmers in study area (Table 4), it was found that $32.5 \%$ farmers followed the standard or near standard amount of using MP for both T. Aus and T. Aman, where the larger group $(60 \%)$ of farmers used greater amount of MP than standard and among these $10 \%$ farmers used very high amount. In case of Boro, half of the respondents $(50 \%)$ farmers used MP in accordance with standard or near standard amount and only $10 \%$ used greater amount than standard amount. The study (Table 5) found that most $(52.5 \%)$ of the respondents used $120-170 \mathrm{Kg} /$ ha of T.S.P; $30 \%$ farmers used $51-100 \mathrm{Kg} / \mathrm{ha}, 11.5 \%$ farmers used $200-250 \mathrm{~kg} / \mathrm{ha}$ and only $6.25 \%$ farmers used $0-50 \mathrm{Kg} / \mathrm{ha}$. 
Table 3. Use of Urea $(\mathrm{Kg} / \mathrm{ha})$ in Study Area and its Comparison With Standard.

\begin{tabular}{|c|c|c|c|}
\hline $\begin{array}{l}\text { Name of } \\
\text { crop }\end{array}$ & Amount used by farmers(\%of farmers) & $\begin{array}{r}\text { Govt. Standard } \\
\text { amount }(\mathrm{Kg} / \mathrm{ha})\end{array}$ & $\begin{array}{l}\text { Differences(Actual } \\
\text { amount-Standard amount) }\end{array}$ \\
\hline \multirow{6}{*}{ T. Aus } & $100-150(5 \%)$ & \multirow{6}{*}{141} & $(-41)-9$ \\
\hline & $151-200(18.8 \%)$ & & $10-59$ \\
\hline & $201-250(45 \%)$ & & $60-109$ \\
\hline & $251-300(23.8 \%)$ & & $110-159$ \\
\hline & $301-350(2.5 \%)$ & & $160-209$ \\
\hline & $351-400(5 \%)$ & & $210-259$ \\
\hline \multirow{6}{*}{ T. Aman } & $100-150(5 \%)$ & \multirow{6}{*}{166} & $(-66)-(-16)$ \\
\hline & $151-200(18.8 \%)$ & & $(-15)-34$ \\
\hline & $201-250(45 \%)$ & & $35-84$ \\
\hline & $251-300(23.8 \%)$ & & $85-134$ \\
\hline & $301-350(2.5 \%)$ & & $135-184$ \\
\hline & $351-400(5 \%)$ & & $185-234$ \\
\hline \multirow{6}{*}{ Boro } & $100-150(5 \%)$ & \multirow{6}{*}{269} & $(-169)-(119)$ \\
\hline & $151-200(18.8 \%)$ & & $(-118)-(-69)$ \\
\hline & $201-250(45 \%)$ & & $(-68)-(-19)$ \\
\hline & $251-300(23.8 \%)$ & & $(-18)-31$ \\
\hline & $301-350(2.5 \%)$ & & $32-81$ \\
\hline & $351-400(5 \%)$ & & $82-231$ \\
\hline
\end{tabular}

Source: Standard amount of Urea provided by MOA [22]

Table 4. Use of M.P. (Kg/ha) in Study Area and differences between Actual Using Amount and Standard Amount.

\begin{tabular}{|c|c|c|c|}
\hline Name of crop & Actual using amount ( $\%$ of farmers) & Govt. Standard amount & $\begin{array}{c}\text { Differences (Actual } \\
\text { amount-Standard amount) }\end{array}$ \\
\hline \multirow{5}{*}{ T. Aus } & $0-50(7.5 \%)$ & \multirow{5}{*}{69} & $(-69)-(-19)$ \\
\hline & $51-100(32.5 \%)$ & & $18-31$ \\
\hline & $101-150(50 \%)$ & & $32-81$ \\
\hline & $151-200(5 \%)$ & & $82-131$ \\
\hline & $201-250(5 \%)$ & & $132-181$ \\
\hline \multirow{5}{*}{ T.Aman } & $0-50(7.5 \%)$ & \multirow{5}{*}{69} & $(-69)-(-19)$ \\
\hline & $51-100(32.5 \%)$ & & $18-31$ \\
\hline & $101-150(50 \%)$ & & $32-81$ \\
\hline & $151-200(5 \%)$ & & $82-131$ \\
\hline & $201-250(5 \%)$ & & $132-181$ \\
\hline \multirow{5}{*}{ Boro } & $0-50(7.5 \%)$ & \multirow{5}{*}{121} & $(-121)-(71)$ \\
\hline & $51-100(32.5 \%)$ & & $(-70)-(-21)$ \\
\hline & $101-150(50 \%)$ & & $(-20)-(29)$ \\
\hline & $151-200(5 \%)$ & & $30-79$ \\
\hline & $201-250(5 \%)$ & & $80-99$ \\
\hline
\end{tabular}

Source:Standard amount of MP provided by MOA [22]

Again comparing the fertilizer and pesticide use by the farmers of the study area with standard amount for TSP (Table 7) it was clearly understood that for T. Aus and T. Aman, $63.7 \%$ farmers used greater amount of TSP than standard amount, although $36.25 \%$ farmers used less amount than standard or near standard. For Boro largest group (52.5\%) of farmers followed the standard amount or near the standard amount of TSP; where $11.25 \%$ used excessive amount of TSP. 
Table 5. Use of M.P. (Kg/Ha) in Study Area and Differences between Actual Using Amount and Standard Amount.

\begin{tabular}{|c|c|c|c|}
\hline Name of crop & $\begin{array}{l}\text { Actual using amount } \\
\text { (\% of farmers) }\end{array}$ & $\begin{array}{c}\text { Govt. Standard } \\
\text { amount }\end{array}$ & $\begin{array}{l}\text { Differences(Actual amount-Standard } \\
\text { amount) }\end{array}$ \\
\hline \multirow{4}{*}{ T. Aus } & $0-50(30 \%)$ & \multirow{4}{*}{101} & $(-101)-(51)$ \\
\hline & $51-100(6.25 \%)$ & & $(-50)-(-1)$ \\
\hline & $120-170(52.5 \%)$ & & $19-69$ \\
\hline & $200-250(11.25 \%)$ & & $99-149$ \\
\hline \multirow{4}{*}{$\begin{array}{c}\mathrm{T} . \\
\text { Aman }\end{array}$} & $0-50(30 \%)$ & \multirow{4}{*}{101} & $(-101)-(51)$ \\
\hline & $51-100(6.25 \%)$ & & $(-50)-(-1)$ \\
\hline & $120-170(52.5 \%)$ & & $19-69$ \\
\hline & $200-250(11.25 \%)$ & & $99-149$ \\
\hline \multirow{4}{*}{ Boro } & $0-50(30 \%)$ & \multirow{4}{*}{131} & $(-101)-(51)$ \\
\hline & $51-100(6.25 \%)$ & & $(-50)-(-1)$ \\
\hline & $120-170(52.5 \%)$ & & $19-69$ \\
\hline & $200-250(11.25 \%)$ & & $99-149$ \\
\hline
\end{tabular}

Source: Standard amount of TSP provided by MOA [22]

Table 6. Comparison between the Standard Amount and the Farmers' Using Amount of Pesticides (Kg/Acre) In Study Area.

\begin{tabular}{|c|c|c|c|}
\hline Name of pesticides & $\begin{array}{l}\text { Actual using amount (\% of } \\
\text { farmers) }\end{array}$ & $\begin{array}{c}\text { Govt. Standard } \\
\text { amount }\end{array}$ & $\begin{array}{c}\text { Differences(Actual amount-Standard } \\
\text { amount) }\end{array}$ \\
\hline \multirow{4}{*}{ Furadan (Carbofuran) } & No amount $(18.8 \%)$ & \multirow{4}{*}{6.80} & -6.80 \\
\hline & $1-5(56.3 \%)$ & & $(-5.80)-(-1.80)$ \\
\hline & $6-10(18.8 \%)$ & & $(-0.80)-3.20$ \\
\hline & $11-15(6.3 \%)$ & & $4.20-8.20$ \\
\hline \multirow{3}{*}{ Diazinon } & No amount $(37.5 \%)$ & \multirow{3}{*}{6.80} & -6.80 \\
\hline & $1-5(50 \%)$ & & $(-5.80)-(-1.80)$ \\
\hline & $6-10(12.5 \%)$ & & $(-0.80)-3.20$ \\
\hline \multirow{3}{*}{ Carbaryl } & No amount $(93.8 \%)$ & \multirow{3}{*}{0.68} & -0.68 \\
\hline & $0.50(1.3 \%)$ & & -0.18 \\
\hline & $0.55(5 \%)$ & & -0.13 \\
\hline
\end{tabular}

Source: Standard amount of pesticides are provided by BRRI [4]

\subsection{Pesticides Used by Farmers in Study Area}

From the field survey it is revealed that $50 \%$ farmers used both of Furadan and Diazinon, 25\% farmers used only Furadan, $12.5 \%$ farmers used only Diazinon, $6.3 \%$ farmers used Ripcord with Furadan and remaining 6.3\% farmers used both of Furadan and carbaryl in the study area (Field survey, 2012) (Table 6).

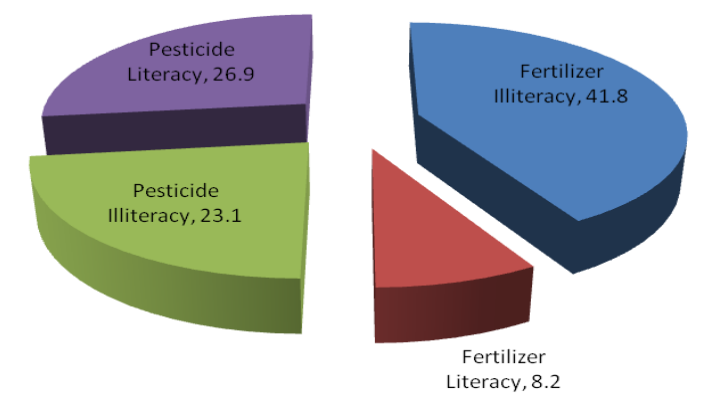

Figure 2. Awareness of Farmers about Hazardous Effect of Pesticide and Fertilizer on Crop production.

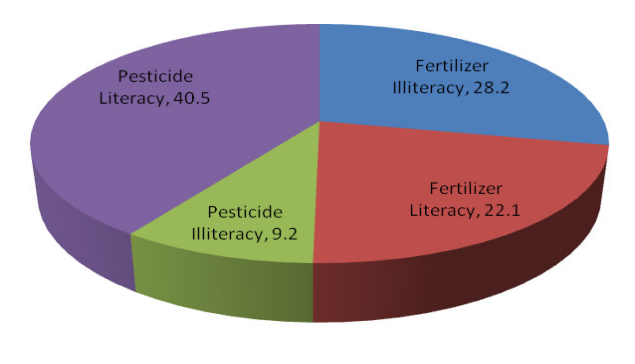

Figure 3. Awareness of Farmers about Hazardous Effect of Pesticide and Fertilizer on Crop production.

During the survey, farmers were questioned whether they were affected or benefitted by using fertilizer and pesticides; then $100 \%$ farmers opined that they were benefitted by using fertilizer and pesticides. Over fertilization, can cause detrimental effects as under fertilization. The study revealed that most of the illiterate farmers were not aware of over application of fertilizer and pesticide into the agricultural fields (Figure 2) and its fertility, environment and crop 
production. Survey also unearthed the perception of the farmers that use of fertilizer and pesticide use might decrease soil fertility, but few thought pesticide agrochemicals had no effects on crop production, Human body, Food cycle and few percent literate about their harmful effect (See figure 3).

\subsection{Perception about Alternatives of Chemical Fertilizer and Pesticide}

When farmers were asked about their interest to use organic fertilizer as alternative for chemical fertilizer, then it was found that half $(50 \%)$ of them were interested to use organic fertilizer, but remaining $50 \%$ were not interested to use organic fertilizer. In case of bio-pesticide it was found that only few (18.8\%) farmers supported the use of bio-pesticide. The survey was conducted to know the personal opinion of the respondents of study area on the use of fertilizer and pesticide on crop production. 32.5\% respondents provided their opinion that fertilizer and pesticides must be used for boost production of crop. 50\% respondents recommend that for better crop production using fertilizer and pesticide cost should be reduced as the cost of these agrochemicals were out of reach for them and only $17.5 \%$ opined that organic fertilizer and bio-pesticides were better than chemical fertilizer and pesticide.

\subsection{Use of Fertilizer and Pesticide in Study Area According to Agrochemical Dealers}

Based on survey on agrochemical dealer, their perception about the use of agrochemicals has been presented here. The study shows that all the agrochemical dealers commented that Urea, TSP, DAP, MOP, Zypsum were used for all types of crop production. They said that there was no any specific fertilizer for particular crop. The agrochemical dealers were asked about the recommendation on the amount of fertilizer should use.

If the recommended amounts provided by dealers (Table 7) are compared with the standard amounts provided by MOA [22], then it will be found that all of the dealers recommended greater amount than the standard amount of MOA [22] for all types of fertilizer.

\subsection{Doses of Different Pesticides}

Table 7. Recommendation for the Amount of Fertilizer Use Provided by Agrochemical Dealers.

\begin{tabular}{|c|c|c|c|c|c|}
\hline \multicolumn{2}{|c|}{ Urea } & \multicolumn{2}{c|}{ MP } & \multicolumn{2}{c|}{ DAP/TSP } \\
\hline $\begin{array}{c}\text { Amount } \\
(\mathrm{kg} / \mathrm{ha})\end{array}$ & Percent (\%) & $\begin{array}{c}\text { Amount } \\
(\mathrm{Kg} / \mathrm{ha})\end{array}$ & Percent (\%) & $\begin{array}{c}\text { Amount } \\
(\mathrm{kg} / \mathrm{ha})\end{array}$ & Percent $(\%)$ \\
\hline 244 & 20 & $165-170$ & 60 & 150 & 60 \\
\hline 300 & 40 & $190-195$ & 20 & 183 & 20 \\
\hline 350 & 40 & $196-200$ & 20 & 172 & 20 \\
\hline
\end{tabular}

According to most of the dealers as respondents, the pesticides used in crop production were Carbofuran, Diazinon, Sypermethrin, Malathion, Di-Methoate, Carbendazin, Rajdhan and Brifer. During the survey on agrochemical dealers it was wanted to know from them about the doses of different pesticides should be used in crop production. In case of Carbofuran, $80 \%$ of the respondents recommended 5-6 Kg/acre and $20 \%$ recommended 3-4 $\mathrm{Kg} /$ acre. For Carbaryl, $80 \%$ of the respondents said that 0.5 $\mathrm{Kg} /$ acre of Carbaryl should be used and 20\% recommended $1 \mathrm{Kg} /$ acre. About the amount of Diazinon, $40 \%$ respondents recommended 3-5 $\mathrm{Kg} / \mathrm{acre}$ and $60 \%$ recommended 6-8Kg/acre. By comparing these respondents recommendation (Table 6) with the standard recommended by BRRI [4], we found that, respondents recommendation is similar or nearly to the standard recommendation.

\subsection{Major Fertilizers Used for Crop Production and Their Amounts}

The study tried to find information about the use of pesticide and fertilizer from agrochemical officers as key informants. The major fertilizers, which were used for crop production, were Urea, T.S.P/D.A.P, M.P., ZnSO4 and Gypsum etc. The informants were also asked about the amount of fertilizer should be used for different crops. All of the informants provided nearly the same amounts (See figure 4).

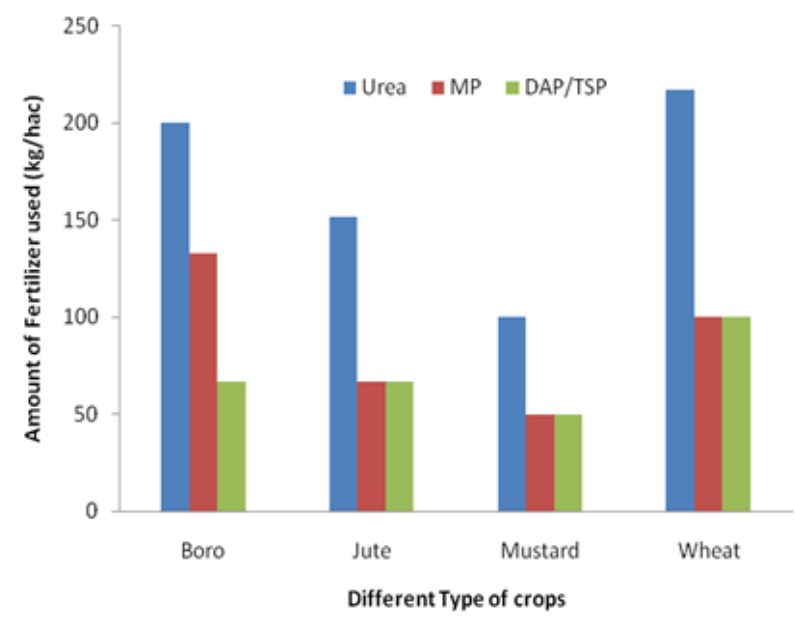

Figure 4. Amount of Fertilizers Recommended by Key Informants 


\subsection{Pesticides used for Different Pest and their Amount}

Key informants were asked about the different pesticides used for different pests. Then it was found from their perception that Carbofuran, Phipronil, Diazinon, Virtaku etc. were important pesticides (Table 8). Figure 5 show the percentage of pesticide was used by farmers to kill different type of pest.

Table 8. Different Pesticides used for Different Pests.

\begin{tabular}{|c|c|c|}
\hline Name of pests & Name of pesticides used & $\begin{array}{c}\text { Amount per } \\
\text { acre }\end{array}$ \\
\hline Mazra & Carbofuran & $4 \mathrm{~kg}$ \\
\hline BPH & Diazinon & $6.8 \mathrm{~kg}$ \\
\hline Pamri & Diazinon & $6.8 \mathrm{~kg}$ \\
\hline Pamri & Sypermethrin & $200 \mathrm{ml}$ \\
\hline
\end{tabular}

The study found from 2012, key informants were agreed to the negative impact of agrochemicals like Cancer, Senseless, Fish killing, Even death, Paralysis, Skin diseases etc.

\section{Percentage of pesticide used}

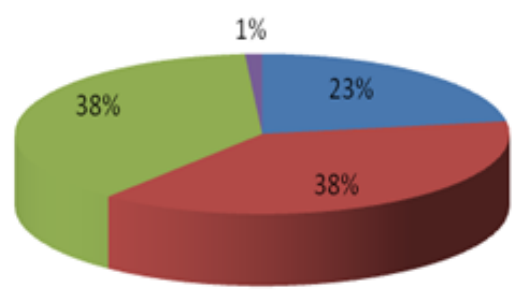

- Mazra, Carbofuran

घBPH, Diazinon

II Pamri, Diazinon

@ Pamri, Sypermethrin

Figure 5. Types of Pesticides Used.

So it is suggested on the use of fertilizer and pesticide in proper amount and Bio-fertilizer and bio-pesticides should apply in crop production in maximum possible extent and reduce the use of agrochemicals.

\section{Conclusions}

From the case study on Shakrail demonstrates that the area is entirely dependent on agricultural activities and paddy is the main agricultural crop in this area. The farmers were found fully dependent on pesticide and fertilizer for boosting up production. But it is unfortunate that most of the farmers did not have proper knowledge about the utilization of fertilizer and pesticide in proper amount, particularly in case of fertilizer either they use greater amount or less amount then the government recommended standard. More than half of the farmers did not have knowledge about the negative impact of over sue of fertilizer, although most of them were conscious about the negative impact of pesticides. Half of the farmers wanted to use bio-fertilizer. But only a few farmers were interested to use bio-pesticides, even many of these farmers did not have idea about bio-pesticides. The agrochemical dealers who supply agrochemical (fertilizer and pesticide) to farmers were not also aware about the proper amount of use of agrochemical and their impacts.

\section{Acknowledgements}

The authors are thankful to the famers, villager, dealers for providing their insights during the study. Thanks are also due to Mr. Ikbal Bahar for his cooperation through laboratory logistics. Finally our heartiest thanks are debt to the Department of Environmental Science and Resource Management at Mawlana Bhashani Science and Technology Univesity, Bangladesh.

\section{REFERENCES}

[1] Ahmad, M, Ahmad M. 2006.Crop .Banglapedia.www.banglapedia.org/httpdocs/ht/c -0376.htm, 2006.

[2] Ayoub AT. 1999. Fertilizer and the environment. Nutrient Cycling in Agroecosystems. 55: 117-121. doi:10.1023/A:1009808118692

[3] Aziz M A. 2005. Country Report, Bangladesh. Proceedings of the Asia regional workshop on the implementation, monitoring and observance of the international code of conduct on the distribution and use of pesticides, FAO of UN.

[4] Bangladesh Rice Research Institute (BRRI). 2007. A handbook on "Adhunik Dhaner Chas" 3rd addition, 2007.

[5] Bangladesh Bureau of Statistics (BBS), 2001. Population Census, 2001, Community Series, zilla Tangail.

[6] Banglapedia, 2003. Asiatic Society Dhaka: Bangladesh.

[7] Barabasz W, Albi ND, Jaśkowska M , Lipiec J. 2002. Biological effects of mineral nitrogen fertilization on soil microorganisms. Polish Journal of Environmental Studies. 11:193-198.

[8] Brundrett MC. 2008. Mycorrhizal associations, the web resource. Available at: http://mycorrhizas.info/index.html (accessed 29 September 2009).

[9] Bi YL, Li XL, Christie P. 2003. Influence of early stages of arbuscular mycorrhiza on uptake of zinc and phosphorus by red clover from a lowphosphorus soil amended with zinc and phosphorus. Chemosphere. 50:831-837. doi:10.1016/S0045-6535(02)00227-8

[10] Carvalho FP. 2006. Agriculture, pesticides, food security and food safety.

[11] Chu C, Plate H, Matthew DL. 1984. Fertilizer injury to potatoes as affected by fertilizer source, rate and placement. American Journal of Potato Research. 55:117-121.

[12] [12]Emmanuel B, Fagbola O, Osonubi O. 2012. Influence of fertiliser application on the occurrence and colonisation of 
arbuscular mycorrhizal fungi (AMF) under maize/Centrosema and sole maize systems Soil Research. 50:76-81. http://dx.doi.org/10.1071/SR11254

[13] Fagbola O, Osonubi O, Mulongoy K. 1998a. Growth of cassava cultivar TMS 30572 as affected by alley-cropping and mycorrhizal inoculation. Biology and Fertility of Soils. 27: 9-14. doi:10.1007/s003740050392.

[14] Government of Bangladesh (GOB). 1995a. "Topic Report on Pesticide and Fertilizer Use in Bangladesh." Ministry of Agriculture, National Minor Irrigation Development Project Consultant report prepared by William Halcrow \& Partners Ltd. (February).

[15] Gosling P, Hodge A, Goodlass G, Bending GD. 2006. Arbuscular mycorrhizal fungi and organic farming. Agriculture, Ecosystems \& Environment. 113: 17-35. doi:10.1016/j.agee.2005.09.009

[16] Harrier LA, Watson CA. 2004. The potential role of arbuscular mycorrhizal (AM) fungi in the bioprotection of plants against soil-borne pathogens in organic and/or other sustainable farming systems. Pest Management Science 60:149-157. doi:10.1002/ps.820.

[17] Hu J, Lin X, Wang J, Dai J, Cui X, Chen R, Zhang J. 2009. Arbuscular mycorrhizal fungus enhances crop yield and P-uptake of maize (Zeamays L.): A field case study on a sandy loam soil as affected by long-term P-deficiency fertilization. Soil Biology \& Biochemistry. 41: 2460-2465. doi:10.1016/j.soilbio.2009.09.002

[18] Ikombo BM, Edwards DG, Asher CJ. 1991. The role of vesicular mycorrhizas (VAM) in phosphorous nutrition of cowpea (Vigna unguiculata, L. Walp.). Australian Journal of Agricultural Research. 42:129-139. doi:10.1071/AR9910129.

[19] Jansa J, Wienken A, Frossard E. 2006. The effects of agricultural practices on arbuscular mycorrhiza fungi. In 'Functions of soils for human societies and environment'. (Eds E Frossard, WEH Blum, BP Warkentin) pp. 89-113. (Geological Society: London)

[20] Mercy MA, Shevashankar G, Bagyaraj DJ. 1990. Mycorrhizal colonization is host dependent and heritable. Plant and Soil. 121: 292-294. doi:10.1007/BF00012324

[21] Miller GT. 2004. Sustaining the Earth, 6th edition. Thompson Learning, Inc. Pacific California. Chapter 9, Pages 211-216

[22] Ministry Of Agriculture (MOA). 2007. Handbook of Agricultural Statistics, December 2007: Agriculture Sector Review, MOA, May, 2004 .Government of Peoples Republic Of Bangladesh.
[23] Muthukumar T, Udaiyan K. 2002. Growth and yield of cowpea as influenced by changes in arbuscular mycorrhiza in response to organic manuring. Journal of Agronomy \& Crop Science 188:123-132. doi:10.1046/ j.1439-037X.2002.00544.X

[24] Mustafi BAA, Islam MR. 2008. Development of Agricultural Policies In Bangladesh. Bangladesh J. Agric. and Environ. 4: 1-8.

[25] Mercy MA, Shevashankar G, Bagyaraj DJ. 1990. Mycorrhizal colonization is host dependent and heritable. Plant and Soil. 121:292-294. doi:10.1007/BF00012324

[26] Osonubi O, Bakare ON, Mulongoy K. 1992. Interactions between drought stress and vesicular-arbuscular mycorrhiza on the growth of Faidherbia albida (syn. Acacia albida) and Acacia nilotica in sterile and non-sterile soils. Biology and Fertility of Soils. 14:159-165. doi:10.1[27] Piotrowski JS, RilligMC. 2008. Succession of arbuscular mycorrhizal fungi: patterns, causes and considerations for organic agriculture. Advances in Agronomy. 97: 111-130. doi:10.1016/S0065-2113(07)00003-X

[27] Piotrowski JS, RilligMC. 2008. Succession of arbuscular mycorrhizal fungi: patterns, causes and considerations for organic agriculture. Advances in Agronomy. 97: 111-130. doi:10.1016/S0065-2113(07)00003-X

[28] Shah, AL, Rahman MS, and Aziz MA. 2008. Outlook for Fertilizer Consumption And Food Production In Bangladesh. Bangladesh J. Agric. and Environ. 4: 1-8. Soil Science Division Bangladesh Rice Research Institute.

[29] Smith AG, Gangolli SD. 2002. Organochlorine chemicals in seafood: occurrence and health concerns. Food and Chemical Toxicology. 40:767-779.

[30] Smith SE, Read DJ. 1997. 'Mycorrhizal symbiosis.' 007/BF00346056.

[31] Tandon HLS, Narayan P. 1990. Fertilizer in Indian Agriculture-past, present and future (1950-2000). FDCO, New Delhi, India.

[32] Wu Q, Xia R, Hu Z. 2006. Effect of arbuscular mycorrhiza on the drought tolerance of Poncirus trifoliata seedlings. Frontiers of Forestry in China. 1:100-104. doi:10.1007/s11461-005-0007-z.

[33] Zhong WH, Cai ZC. 2007. Long-term effects of inorganic fertilizers on microbial biomass and community functional diversity in a paddy soil derived from quaternary red clay. Applied Soil Ecology. 36:84-91. doi:10.1016/j.apsoil.2006.12.001 